\title{
Effects of one haustorium-inducing quinone DMBQ on growth and development of root hemiparasitic plant Monochasma savatieri
}

\section{Lanlan Chen' ${ }^{1}$ Zaibiao Zhu' ${ }^{1}$ Qiaosheng Guo ${ }^{*}$ Jun Guo ${ }^{1}$ Zhigang Huang ${ }^{2}$ Yongtao Shi $^{1}$ Zhencui Wen ${ }^{2}$}

${ }^{1}$ Institute of Chinese Medicinal Materials, Nanjing Agricultural University, Nanjing, 210095, China. E-mail: gqs@njau.edu.cn.
${ }^{*}$ Corresponding author.

${ }^{2}$ Huizhou Jiuhui Pharmaceutical Co., Ltd., Huizhou, 516007, China.

ABSTRACT: Monochasma savatieri Franch. ex Maxim is a perennial, parasitic herb used in traditional Chinese medicine and its wild resources have decreased sharply in recent years due to destructively harvesting and habitat destruction. Haustorium formation is a key event of parasites, but the concentrations of haustorium-inducing factors vary with species and cultivation conditions. In this study, we investigated the effects of the 2,6-dimethoxy-p-benzoquinone (DMBQ) concentration and cultivation density on the growth traits, haustorium formation and biomass of $M$. savatieri in the absence of a host plant. The results showed that both the DMBQ concentration and cultivation density regulated growth traits, haustorium formation and biomass in $M$. savatieri. The number of haustoria was significantly positively correlated with seedling height, maximum root length, the number of root tips and total dry weight. Membership function analysis revealed an overall greater increase in growth traits, haustorium formation and biomass when M. savatieri was treated with $10 \mu \mathrm{mol} \cdot \mathrm{L}^{-1} D M B Q$ and grew solitarily. These results offer an understanding of growth in $M$. savatieri influenced by the $D M B Q$ concentration and cultivation density, which may aid in the establishment of a comprehensive cultivation system for $M$. savatieri or similar plants.

Key words: artificial cultivation, density, $D M B Q$, fuzzy membership function, growth promotion.

Efeitos de quinona indutor de haustório (DMBQ) no crescimento e desenvolvimento de plantas hemiparasitárias de raiz Monochasma savatieri

RESUMO: Monochasma savatieri Franch. O ex Maxim é uma erva parasitária aperene usada na medicina tradicional chinesa suas fontes diminuíram acentuadamente nos últimos anos devido à colheita destrutiva e à destruição de habitats e condições de sobrevivência no campo. Neste estudo, investigamos os efeitos da concentração de 2,6-dimetoxi-p-benzoquinona (DMBQ) e densidade de cultivo sobre as características de crescimento, formação de haustório e biomassa de M. savatieri na ausência de uma planta hospedeira. Os resultados mostraram que a concentração de DMBQ e a densidade de cultivo regularam as características de crescimento, a formação de haustório e a biomassa em M. savatieri. O número de haustórios foi significativamente correlacionado positivamente com a altura das plântulas, comprimento máximo das raizes, número de pontas das raizes e peso seco total. Revelou também um aumento geral nas características de crescimento, formação de haustório e biomassa quando M. savatieri foi tratado com $10 \mu \mathrm{mol} \cdot$ L-1DMBQ e cresceu solitariamente. Esses resultados oferecem uma compreensão do crescimento de $M$. savatieri influenciado pela concentração de DMBQ e densidade de cultivo, o que pode ajudar no estabelecimento de um sistema abrangente de cultivo para plantas similares de M. savatierior. Palavras-chave: cultivo artificial, densidade, DMBQ, função de associação difusa, promoção do crescimento.

\section{INTRODUCTION}

Parasitic plant lineages are found in 28 families and include approximately 4,500 species, representing $1 \%$ of dicotyledonous angiosperm species (HEIDE-JØRGENSEN, 2013). Green autotrophic plants produce carbohydrates by photosynthesis, while parasitic plants have developed a distinctive heterotrophic lifestyle in which they benefit from nutrients and water provided by their hosts (YOSHIDA et al., 2016).

Hosts usually have decisive effects on the growth and development of parasitic plants. In natural conditions, seedlings of Cordylanthus would reach maturity only when they are in contact with appropriate host roots (CHUANG et al., 
1971). Imperata cylindrica, Prunella vulgaris, and Chrysanthermum indicum are more efficient in increasing the biomass of pot-cultured Thesium chinense than the other hosts (GUO et al., 2010). However, without attachment to a suitable host, the seedling development of Aureolaria pedicularia and A. grandiflora is halted in both culture and nature (MUSSELMAN, 1969). When grown without a host, Nuytsia floribunda shows a greater plant dry weight than it does in association with an unsuitable host (CALLADINE et al., 2000).

All parasitic plants share a common multicellular organ called the haustorium, which establishes direct host-parasite interactions with host plants, including host attachment, tissue penetration, vasculature connection, and material transfer (YOSHIDA et al., 2012). The haustorium dynamically changes its structure and function during the interactions between parasitic plants and host plants. Early in the process of parasitization, the haustoria establish physical connections with each other and invade the hosts. Later in the process, vascular cells develop in the haustoria, which aid in extracting water and carbohydrates from the host (YOSHIDA et al., 2012).

The formation of haustoria can be induced in response to chemicals exuded by the host. These host-derived chemicals are referred to as haustorium-inducing factors (HIFs), which include quinones, hydroquinones, phenolic acids, and flavonoids (CHANG et al., 1986; ALBRECHT et al.,1999). Among all these HIFs, 2,6-dimethoxy$p$-benzoquinone (DMBQ) was the first HIF that was isolated directly from host roots (CHANG et al., 1986). As a product of lignin degradation, DMBQ is widely distributed in the plant kingdom (WESTWOOD et al., 2010). Further studies on the biogenesis, activity, and recognition of chemical signaling by DMBQ have revealed its involvement in the first steps of the haustorium developmental pathwayin several parasitic plants (KIM et al., 1998; KEYES et al., 2000; BANDARANAYAKE et al., 2010). In addition, DMBQ is commonly utilized to initiate haustorium development in different hemiparasitic plants due to its validity and commercial availability. Accumulating evidence has shown that the optimal DMBQ concentrations inducing haustorium formation vary with hemiparasitic species and cultivation conditions (TOMILOV et al., 2005; NGO et al., 2013; CUI et al., 2016).

Monochasma savatieri Franch. ex Maxim is a root hemiparasite belonging to the Orobanchaceae and is only distributed in Southeast China and
Kyushu (Amakusa Islands) of Japan (YAMAZAKI, 1993; HONG et al., 1998). In the wild, M. savatieri grows well on wet and sunny hills, and a total of 27 host species parasitized by $M$. savatieri have been identified (ZHANG et al., 2015). Activities such as antioxidant, antiviral, antibacterial, and antiinflammatory properties are derived from different bioactive compounds produced by $M$. savatieri (LI et al., 2012b; LIU et al., 2013; SHI et al., 2013). $M$. savatieri has long been listed as an endangered and threatened species in Japan (ENVIRONMENT AGENCY of JAPAN, 2000). According to our survey conducted in 2016, wild M. savatieri resources have declined sharply in China due to habitat destruction and over exploitation (data not shown). Although there is an urgent need to develop an artificial cultivation system for $M$. savatieri, there are only two reports on its tissue culture (YANG, 2009; ZHANG et al., 2017). These studies ignored (or were not aware of) the impacts on haustorium formation, which is critical to successful cultivation of $M$. savatieri.

Given the lack of artificial cultivation methods associated with haustorium formation, we designed this study to understand the growth responses of $M$. savatieri to the DMBQ concentration and cultivation density. A better understanding of growth and haustorium formation in $M$. savatieri will contribute to its successful cultivation and lay a foundation for further studies of $M$. savatieri or similar plants.

\section{MATERIALS AND METHODS}

\section{Materials and experimental design}

The seed capsules of $M$. savatieri were collected in May 2017 from Yongfeng, Jiangxi Province, China, and then exposed to air indoors, after which they were stored in envelopes at $4{ }^{\circ} \mathrm{C}$ until use. DMBQ was obtained from Thermo Fisher Scientific Inc. (Waltham, USA). Gibberellin was obtained from Shanghai Riyong Biological Technology Co., Ltd. (Shanghai, China). Mercuric chloride was obtained from Chengdu Jinshan Chemical Reagent Co., Ltd. (Chengdu, China). KOH was purchased from Xilong Scientific Co., Ltd. (Shantou, China). Safranin O solution was purchased from Shanghai Yuanye BioTechnology Co., Ltd. (Shanghai, China). Chloral hydrate was purchased from Sinopharm Chemical Reagent Co., Ltd. (Shanghai, China). Phosphatebuffered saline (PBS) and glycerol were purchased from Beijing Solarbio Science \& Technology Co., Ltd. (Beijing, China).A stock solution of DMBQ $\left(2000 \mu \mathrm{mol} \cdot \mathrm{L}^{-1}\right)$ was stored at $-20{ }^{\circ} \mathrm{C}$ for further use. 
Test DMBQ solutions of 0.1 to $1000 \mu \mathrm{mol} \cdot \mathrm{L}^{-1}$ were prepared in distilled water just before use.

A comprehensive test was the basis of the experimental design. In this experiment, the DMBQ concentration and cultivation density were included to determine of the optimal DMBQ concentration and cultivation density in M. savatieri. Six DMBQ concentrations and three density gradients were used for the study: (1) $0,0.1,1,10,100$, and $1000 \mu \mathrm{mol} \cdot \mathrm{L}^{-1}$ DMBQ and (2) one seedling, two seedlings or four seedlings in each cell. In total, there were eighteen treatments, and each treatment was replicated for three times.

\section{Haustorium induction and growth conditions}

To promote germination, $M$. savatieri seeds were surface sterilized in $0.1 \%$ (w/w) mercuric chloride for $8 \mathrm{~min}$, rinsed thoroughly with sterile deionized water and soaked in an $800 \mathrm{mg} \cdot \mathrm{L}^{-1}$ gibberellin solution for $24 \mathrm{~h}$. The seeds were then sown in individual cells of 105-cell seed starter trays (54 cm long, $28 \mathrm{~cm}$ wide, and $5 \mathrm{~cm}$ deep), which contained $30 \mathrm{~g}$ of nutritive soil and fine sand (1:2, $\mathrm{v} / \mathrm{v})$, in March 17, 2018. This soil substrate was determined in a previous study carried out in our laboratory and showed similar soil properties to the soil types found in the natural habitat of $M$. savatieri. The substrate mixture was autoclaved at $121^{\circ} \mathrm{C}$ for 1 h. The autoclaved substrate mixture contained 70.95 $\mathrm{mg} \cdot \mathrm{kg}^{-1}$ alkali-hydrolyzable nitrogen, $7.65 \mathrm{mg} \cdot \mathrm{kg}^{-1}$ available phosphorus and $173.45 \mathrm{mg} \cdot \mathrm{kg}^{-1}$ available potassium. The $\mathrm{pH}$ was 5.5 . The seed starter trays were placed in a $25^{\circ} \mathrm{C}$ growth chamber with $12 \mathrm{~h}$ of light and $12 \mathrm{~h}$ of dark according to the conditions described previously (CHEN et al., 2018).

Four weeks after sowing (day 28), at the twoleaf stage, seedlings of the same height (approximately $5 \mathrm{~mm}$ ) were thinned to the corresponding density per cell. One week later (day 35), 0.1, 1, 10, 100, and $1000 \mu \mathrm{mol} \cdot \mathrm{L}^{-1} \mathrm{DMBQ}$ solutions were applied $(3 \mathrm{~mL}$ per cell $)$ to the appropriate cells. Control $\left(0 \mu \mathrm{mol} \cdot \mathrm{L}^{-1}\right.$ DMBQ) seedlings were treated with $3 \mathrm{~mL}$ of distilled water. After two weeks (day 49), equal volumes of five DMBQ solutions and distilled water were applied to the $M$. savatieri roots again. The seed starter trays were watered to maintain the same water content by adding an equal volume of distilled water every other day, and were fully randomized and re-randomized at each watering to reduce position effects.

\section{Determination of plant growth}

Thirteen weeks after sowing (day 91), the growth of $M$. savatieri was recorded by harvesting plants. At harvest, the whole plants of $M$. savatieri plants in each cell were carefully dug up together and then washed thoroughly in running water. The plants were placed in round Petri dishes containing distilled water, and seedling height (SH), maximum root length (RL), the number of leaves (L) and root tips (RT) were determined. Leaf morphological indexes including leaf length (LL), leaf width (LW) and leaf area (LA) were measured using Image $J$ (version 1.48; National Institutes of Health, USA). The total dry weight (DW) was determined after oven drying at $80{ }^{\circ} \mathrm{C}$ for $72 \mathrm{~h}$.

To facilitate the recognition of haustoria, whole roots were cleared for $16 \mathrm{~h}$ in clearing solution $\left(2.5 \mathrm{~g} \cdot \mathrm{mL}^{-1}\right.$ chloral hydrate and $50 \%[\mathrm{v} / \mathrm{v}]$ glycerol) as described previously with minor modifications (CUI et al., 2016). Haustoria were recognized based on the following criteria. (1) The haustoria are hemispherical or globular in shape due to the swelling of the haustorium-forming site in the root (YOSHIDA et al., 2016). (2) The haustoria do not rupture the parasite epidermis (TOMILOV et al., 2005). The number of haustoria $(\mathrm{H})$ was counted with a bright-field microscope (Leica DM6B). For the examination of xylem bridge formation by haustoria in self-parasitism, the sampled roots were processed according to the method of Cui (2016) with slight modification. After clearing and staining, the roots were soaked in a clearing solution for $1 \mathrm{~h}$.

\section{Statistical analysis}

Univariate analysis of variance (ANOVA) of the data was performed with the aid of IBM Statistical Product and Service Solutions (SPSS) software (version 22, IBM Inc., USA) for the data. Duncan's multiple range tests were used for the comparison of means. In addition, Pearson's correlation coefficients were determined to understand the relationships between the tested indicators in $M$. savatieri. The fuzzy membership function (SHENG et al., 2014) was utilized to determine the most advantageous experimental approach when the goal is to understand the comprehensive effects of different treatments. Membership function values $\mathrm{R}\left(\mathrm{X}_{\mathrm{i}}\right)$ were calculated as follows:

$$
\mathrm{R}\left(X_{i}\right)=\frac{X_{i}-X_{\min }}{X_{\max }-X_{\min }}
$$

In the formula, $X_{i}$ indicates the measured value of an index; $X_{\min }$ indicates the minimum value of the index among all the treatments; $X_{\max }$ indicates the maximum value of the index among all the treatments; and $\mathrm{R}\left(\mathrm{X}_{\mathrm{i}}\right)$ indicates the membership function values for the measured values of the corresponding indexes. 


\section{RESULTS}

Seedling height and maximum root length in relation to $D M B Q$ concentrations and cultivation densities

M. savatieri showed obvious seedling height and maximum root length responses to variations in DMBQ concentrations and cultivation densities (Table 1). Additionally, there was significant synergy between DMBQ concentrations and cultivation densities $(F=8.92, P<0.01)$. On average, the seedling height and maximum root length of $M$. savatieri were $8.9 \mathrm{~mm}$ and $4.45 \mathrm{~cm}$, respectively (Table 2), at 13 weeks after sowing, which indicated the characteristic of slow long-term growth in the seedling stage. Compared with the control, treatments with 1 to $10 \mu \mathrm{mol} \cdot \mathrm{L}^{-1} \mathrm{DMBQ}$ significantly increased seedling height, independent of the number of cocultured $M$. savatieri, but the strongest effect was observed when plants grew solitarily (Table 2). In the control and the treatments with high concentrations of DMBQ (100 to $\left.1000 \mu \mathrm{mol} \cdot \mathrm{L}^{-1}\right)$, seedling height was significantly higher at a moderate density (two plants per cell) than at other densities.

For root development, the density treatment involving one plant resulted in better-developed roots under most DMBQ regimes, including $0.1,10$, and $1000 \mu \mathrm{mol} \cdot \mathrm{L}^{-1} \mathrm{DMBQ}$. Treatment with $10 \mu \mathrm{mol} \cdot \mathrm{L}^{-1}$ DMBQ increased the maximum root length of $M$. savatieri the most when plants grew solitarily (Table 2 ). In contrast, the high cultivation density (four plants per cell) had negative effects on the maximum root length of $M$. savatieri at all DMBQ concentrations except for $1 \mu \mathrm{mol} \cdot \mathrm{L}^{-1} \mathrm{DMBQ}$, and the weakest root development was observed in the control.

\section{Leaf indexes respond differentially to $D M B Q$ concentrations and cultivation densities}

Similar patterns of variations were observed regarding the number of leaves, total leaf length, total leaf width and total leaf area of $M$. savatieri, independent of the different treatment combinations (Figure 1). The number of leaves, total leaf length and total leaf width of the plants treated with $0.1,1,10,100$, and $1000 \mu \mathrm{mol} \cdot \mathrm{L}^{-1} \mathrm{DMBQ}$ decreased with increasing density. Furthermore, the number of leaves, total leaf length, total leaf width and total leaf area of $M$. savatieri first increased with an increasing DMBQ concentration and then showed a downward trend when plants grewat low or high densities (Figure 1). In addition, the results of variance analysis showed that both the DMBQ concentration and cultivation density had significant effects on the leaf indexes of $M$. savatieri (Table 1).

When plants grew solitarily, the number of leaves, total leaf length, total leaf width and total leaf area of plants treated with $1 \mu \mathrm{mol} \cdot \mathrm{L}^{-1} \mathrm{DMBQ}$ were significantly greater $(P<0.05)$ than those in the control, being increased by $49.93 \%, 64.15 \%, 44.73 \%$ and $70.12 \%$, respectively. When this concentration was exceeded, the positive effects of DMBQ on leaf development decreased with increasing concentrations (Figure 1). Compared with the control, the total leaf length and total leaf area of the plants treated with $1000 \mu \mathrm{mol} \cdot \mathrm{L}^{-1} \mathrm{DMBQ}$ were decreased by $24.70 \%$ and $29.41 \%$, respectively, when plants grew at a moderate

Table 1 - UNIANOVA (general linear model, univariate) results (F-values) for the effects of the seedling height, maximum root length, number of leaves, total leaf length, total leaf width, total leaf area, number of root tips, number of haustoria and total dry weight of M. savatieri.

\begin{tabular}{lccc}
\hline Variates & DMBQ concentration & Plant density & DMBQ concentration $\times$ Cultivation density \\
\hline Seedling height & $55.27^{* *}$ & $19.51^{* *}$ & $8.92^{* *}$ \\
Maximum root length & $20.92^{* *}$ & $53.46^{* *}$ & $10.91^{* *}$ \\
No. of leaves & $9.44^{* *}$ & $26.59^{* *}$ & 0.99 \\
Total leaf length & $25.98^{* *}$ & $158.91^{* *}$ & $9.35^{* *}$ \\
Total leaf width & $20.91^{* *}$ & $147.47^{* *}$ & $3.09^{* *}$ \\
Total leaf area & $20.86^{* *}$ & $80.06^{* *}$ & $3.79^{* *}$ \\
No. of root tips & $29.03^{* *}$ & $56.68^{* *}$ & $13.02^{* *}$ \\
No. of haustoria & $60.25^{* *}$ & $64.76^{* *}$ & $10.47^{* *}$ \\
Total dry weight & $27.74^{* *}$ & $103.39^{* *}$ & 1.29 \\
\hline
\end{tabular}

** indicates following level of significance: $P<0.01$. 
Table 2 - Variations in the seedling height and maximum root length of $M$. savatieri grown in six DMBQ concentrations at three cultivation densities.

\begin{tabular}{lcccccc}
\hline DMBQ concentration $\left(\mu \mathrm{mol} \cdot \mathrm{L}^{-1}\right)$ & \multicolumn{3}{c}{ Seedling height $(\mathrm{mm})$} & \multicolumn{3}{c}{ Maximum root length $(\mathrm{cm})$} \\
\hline & One plant & Two plants & Four plants & One plant & Two plants & Four plants \\
0 & $6.6 \pm 0.3 \mathrm{j}$ & $8.3 \pm 0.2 \mathrm{de}$ & $7.2 \pm 0.1 \mathrm{hij}$ & $3.6 \pm 0.2 \mathrm{bcd}$ & $3.5 \pm 0.2 \mathrm{cde}$ & $2.7 \pm 0.1 \mathrm{~g}$ \\
0.1 & $9.5 \pm 0.3 \mathrm{ab}$ & $9.4 \pm 0.3 \mathrm{abc}$ & $7.8 \pm 0.4 \mathrm{efgh}$ & $4.3 \pm 0.1 \mathrm{a}$ & $4.0 \pm 0.2 \mathrm{~b}$ & $3.5 \pm 0.2 \mathrm{~cd}$ \\
1 & $9.9 \pm 0.27 \mathrm{a}$ & $9.1 \pm 0.2 \mathrm{bc}$ & $8.8 \pm 0.5 \mathrm{~cd}$ & $3.3 \pm 0.2 \mathrm{de}$ & $3.7 \pm 0.3 \mathrm{bcd}$ & $3.9 \pm 0.2 \mathrm{~b}$ \\
10 & $9.4 \pm 0.4 \mathrm{abc}$ & $9.0 \pm 0.5 \mathrm{bc}$ & $8.1 \pm 0.2 \mathrm{ef}$ & $4.5 \pm 0.3 \mathrm{a}$ & $4.4 \pm 0.2 \mathrm{a}$ & $3.2 \pm 0.1 \mathrm{ef}$ \\
100 & $7.3 \pm 0.5 \mathrm{hi}$ & $8.1 \pm 0.5 \mathrm{efg}$ & $7.6 \pm 0.6 \mathrm{fgh}$ & $3.4 \pm 0.1 \mathrm{cde}$ & $3.8 \pm 0.0 \mathrm{bc}$ & $3.0 \pm 0.0 \mathrm{f}$ \\
1000 & $6.8 \pm 0.3 \mathrm{ij}$ & $7.5 \pm 0.4 \mathrm{fgh}$ & $7.4 \pm 0.2 \mathrm{ghi}$ & $4.0 \pm 0.2 \mathrm{~b}$ & $3.6 \pm 0.3 \mathrm{~cd}$ & $3.3 \pm 0.2 \mathrm{de}$ \\
\hline
\end{tabular}

Data are presented as the mean \pm s.e. of three replicates. Different letters for the same indicator indicate a significant difference $(P<0.05)$.

density (two plants per cell), which indicated that an excessive DMBQ concentration is not conductive to the leaf development of M. savatieri.

Root and haustorium formation under different $D M B Q$ concentrations and cultivation densities

During seed germination and seedling growth (i.e., in a period of 4 months), M. savatieri presented fibrous root systems associated with DMBQ concentrations (Figure 4). As a hemiparasite, $M$. savatieri usually forms haustoria on lateral roots, and we determined the number of root tips in the present study. In comparison with the control, a moderate concentration of DMBQ $\left(10 \mu \mathrm{mol} \cdot \mathrm{L}^{-1}\right)$ increased the number of root tips independent of the cultivation density, but the greatest increase (58.89\%) was observed when $M$. savatieri grew solitarily (Figure 2a). When plants grew at a low, moderate and high density, $1000 \mu \mathrm{mol} \cdot \mathrm{L}^{-1} \mathrm{DMBQ}$ decreased the numbers of root tips by $15.32 \%, 18.51 \%$ and $0.89 \%$, respectively. With regard to treatments with $0.1,10$ and $100 \mu \mathrm{mol} \cdot \mathrm{L}^{-1} \mathrm{DMBQ}$, the number of root tips was decreased with an increasing cultivation density. Compared with growth at four plants per cell, $M$. savatieri exhibited significantly more root tips when grown solitarily $(P<0.05)$, indicating that more nutrients can be absorbed from the soil substrate.

To understand the effects of the DMBQ concentration and cultivation density on the haustorium formation, we counted the number of haustoria per plant. Variance analysis showed that both the DMBQ concentration and cultivation density had significant effects on the haustorium formation of M. savatieri (Table 1). With regard to the treatments with $0.1,1,100$ and $1000 \mu \mathrm{mol} \cdot \mathrm{L}^{-1} \mathrm{DMBQ}$, the plants grown at a moderate (two plants per cell) or high density (four plants per cell) formed more haustoria than those that grew solitarily $(P<0.05)$. Compared with the control, when the plants grew at a low (one plant per cell) or moderate density (two plants per cell), $10 \mu \mathrm{mol} \cdot \mathrm{L}^{-1} \mathrm{DMBQ}$ increased the number of haustoria by $286.89 \%$ and $105.82 \%$, respectively. With increasing DMBQ concentrations, the plants growing at a high density (four plants per cell) first showed an increase and then showed a downward trend (Figure 2b).

Dry weight under different $D M B Q$ concentrations and cultivation densities

The results of variance analysis showed that both the DMBQ concentration and cultivation density had significant effects on the dry weight of M. savatieri (Table 1). We observed that the total dry weight of $M$. savatieri decreased with an increasing cultivation density, independent of the DMBQ concentration (Figure 3). Plants grown solitarily accumulated the maximum biomass, and plants grown at a high density (four plants per cell) accumulated significantly lower biomass $(P<$ 0.05). When grown at the same density, the DMBQ concentration increased the accumulation of biomass in M. savatieri, with the peak biomass occurring at 1 $\mu \mathrm{mol} \cdot \mathrm{L}^{-1} \mathrm{DMBQ}$ (Figure 3 ). However, as the DMBQ concentration increased further, this positive effect on the dry weight of $M$. savatieri was weakened, and the plants grown with $1000 \mu \mathrm{mol} \cdot \mathrm{L}^{-1} \mathrm{DMBQ}$ ultimately accumulated the minimum biomass.

\section{Correlation analysis}

The most significantly positive correlations were found between leaf indexes (L, LL, LW, LA), which were all significantly positively correlated with 



Figure 1 - Variations in the number of leaves (a), total leaf length (b), total leaf width (c) and total leaf area (d) of $M$. savatieri grown in six DMBQ concentrations at three cultivation densities. Bars with different letters indicate a significant difference $(\mathrm{P}<0.05)$. 


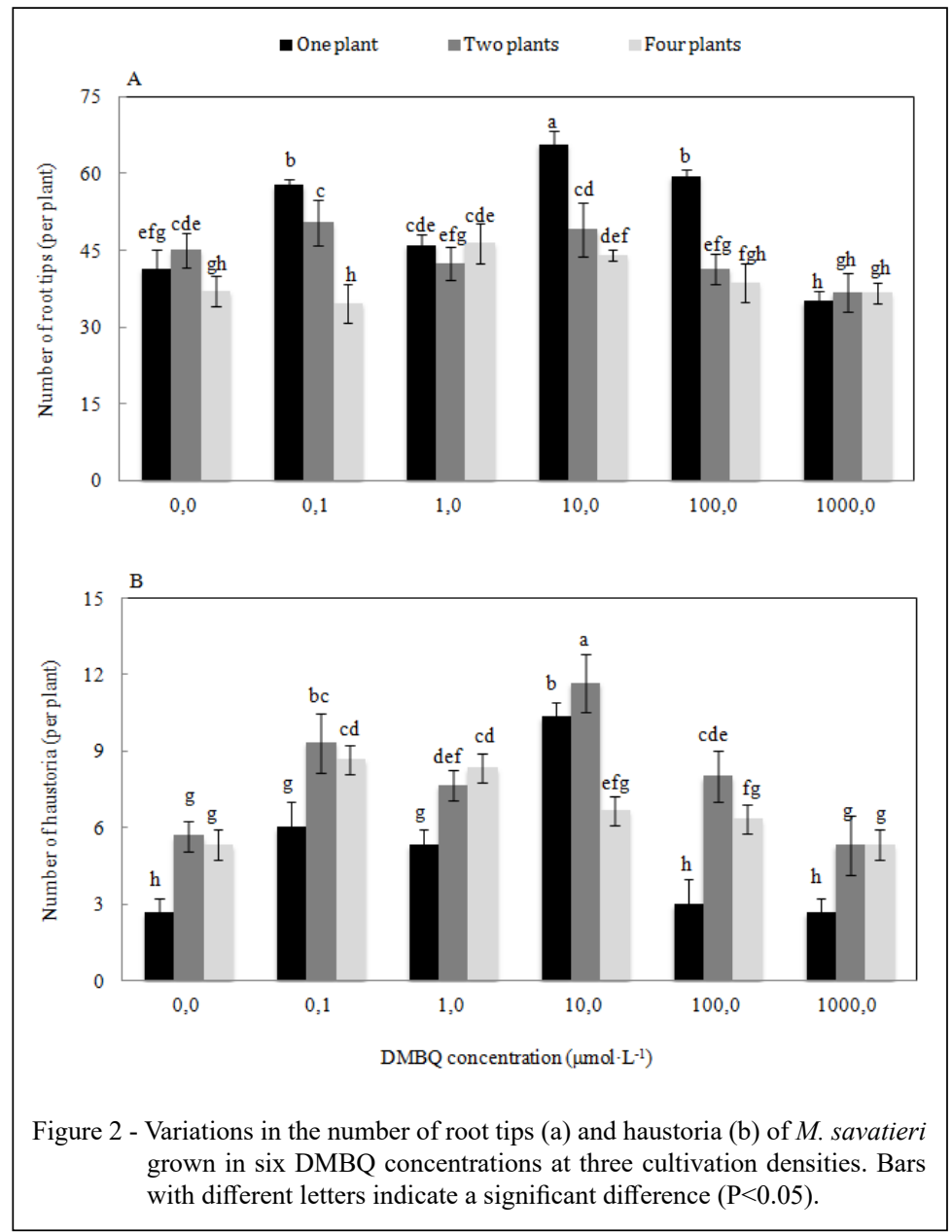

SH, RT and DW, suggesting that the leaf status played an important role in M. savatieri development and biomass accumulation (Table 3). The values of DW were significantly positively correlated with those of all the other parameters $\mathrm{SH}, \mathrm{RL}, \mathrm{L}, \mathrm{LL}, \mathrm{LW}, \mathrm{LA}$, RT, H), which indicated the close connection between these parameters.

The values of $\mathrm{H}$ were significantly positively correlated with those of SH, RL, RT and DW (Table 3). This result suggested that a possible intimacy relationship exists between haustorium formation and biomass accumulation in M. savatieri. Regarding the further verification of specific causality, it will be investigated in our future studies.

\section{Membership function analysis}

Compared with the control, M. savatieri treated with $0.1,1$ and $10 \mu \mathrm{mol} \cdot \mathrm{L}^{-1} \mathrm{DMBQ}$ showed better comprehensive performance under all tested cultivation densities. Moreover, M. savatieri supplemented with the same concentration of DMBQ presented the maximum membership function values when grown solitarily, which suggested that the DMBQ concentration and cultivation density had different effects on the growth and development of M. savatieri (Table 3, Table 4). Taken together, the membership function value was the greatest when $M$. savatieri was treated with $10 \mu \mathrm{mol} \cdot \mathrm{L}^{-1} \mathrm{DMBQ}$ and grew solitarily, which indicated that this was the best treatment combination in this evaluation system (Table 4).

\section{DISCUSSION}

In this study, we observed significant differences in the growth responses of $M$. savatieri between the different DMBQ concentration treatments (Table 1, Table 4). Studies on haustorium induction with DMBQ have been reported in many hemiparasitic

Ciência Rural, v.50, n.3, 2020. 


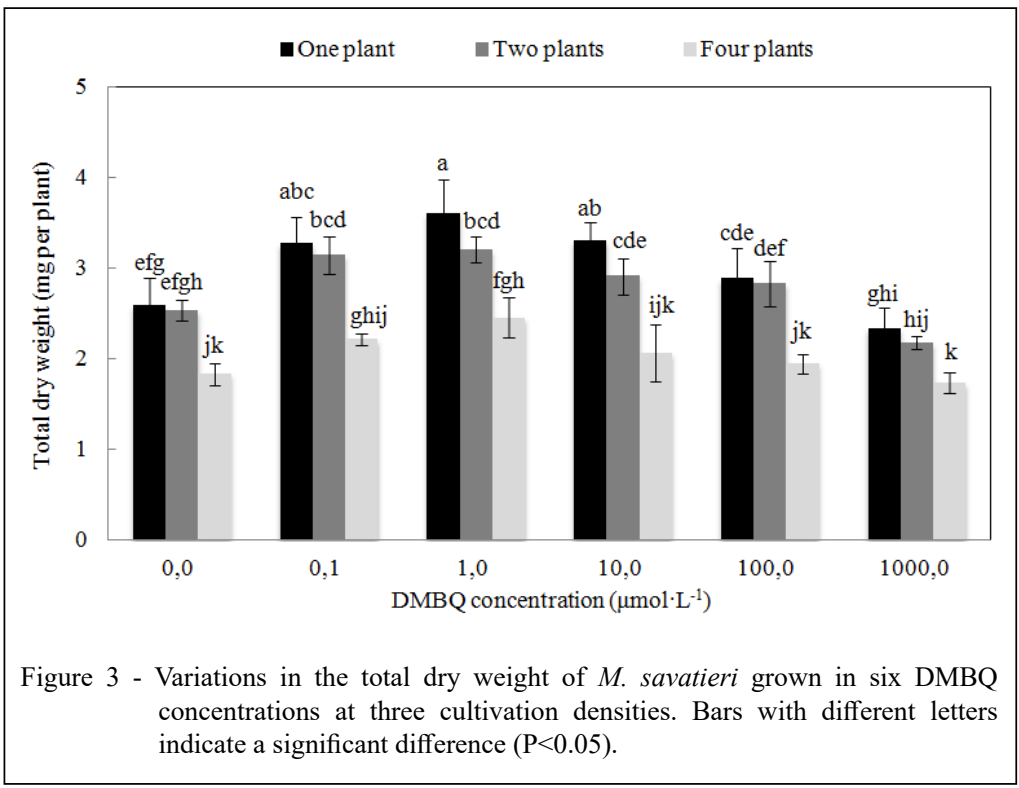

plants; however, the optimal concentrations vary with species and cultivation conditions. In the hemiparasitic plant Phtheirospermum japonicum, a $10 \mu \mathrm{mol} \cdot \mathrm{L}^{-1} \mathrm{DMBQ}$ solution has been dropped onto its roots to induce haustoria (ISHIDA et al., 2016). In contrast, 10 or $100 \mu \mathrm{mol} \cdot \mathrm{L}^{-1} \mathrm{DMBQ}$ is commonly used to induce haustoria in Triphysaria versicolor (NGO et al., 2013). Similarly, our data showed that compared with the control, $10 \mu \mathrm{mol} \cdot \mathrm{L}^{-1} \mathrm{DMBQ}$ significantly promoted $M$. savatieri growth by increasing seedling height, maximum root length (Table 2), total leaf area
(Figure 1), haustorium formation (Figure 2), and total dry weight (Figure 3). However, suppression of growth occursin plants growing together with unsuitable hosts happens in many hemiparasitic species, such as Nuytsia floribunda (CALLADINE et al., 2000) and T. chinense (GUO et al., 2010). From a practical perspective, the promotion effects of an optimal DMBQ concentration on growth provide good potential for the artificial cultivation of M. savatieri. M. savatieri develops a vestigial root system similar to other root hemiparasites, limiting

Table 3 - Correlation analyses of seedling height (SH), maximum root length (RL), the number of leaves (L), total leaf length (LL), total leaf width (LW), total leaf area (LA), the number of root tips (RT), the number of haustoria (H) and total dry weight (DW) in M. savatieri.

\begin{tabular}{|c|c|c|c|c|c|c|c|c|c|}
\hline & $\mathrm{SH}$ & RL & $\mathrm{L}$ & LL & LW & LA & RT & $\mathrm{H}$ & DW \\
\hline SH & 1 & - & - & - & - & - & - & - & - \\
\hline RL & $0.43^{* *}$ & 1 & - & - & - & - & - & - & - \\
\hline $\mathrm{L}$ & $0.64^{* *}$ & $0.41^{* *}$ & 1 & - & - & - & - & - & - \\
\hline LL & $0.59^{* *}$ & $0.40^{* *}$ & $0.82^{* *}$ & 1 & - & - & - & - & - \\
\hline LW & $0.58^{* *}$ & $0.53^{* *}$ & $0.81^{* *}$ & $0.86^{* *}$ & 1 & - & - & - & - \\
\hline LA & $0.59^{* *}$ & $0.48^{* *}$ & $0.81^{* *}$ & $0.84^{* *}$ & $0.81^{* *}$ & 1 & - & - & - \\
\hline RT & $0.52^{* *}$ & $0.55^{* *}$ & $0.57^{* *}$ & $0.58^{* *}$ & $0.69^{* *}$ & $0.54^{* *}$ & 1 & - & - \\
\hline $\mathrm{H}$ & $0.58^{* *}$ & $0.46^{* *}$ & 0.26 & 0.06 & 0.15 & 0.20 & $0.27^{*}$ & 1 & - \\
\hline DW & $0.67^{* *}$ & $0.54^{* *}$ & $0.81^{* *}$ & $0.81^{* *}$ & $0.86^{* *}$ & $0.83^{* *}$ & $0.62^{* *}$ & $0.28^{*}$ & 1 \\
\hline
\end{tabular}

${ }^{*}$ indicates following level of significance: $0.01<P<0.05$.

${ }^{* *}$ indicates following level of significance: $P<0.01$. 
Table 4 - The membership function values of seedling height ( $\mathrm{SH})$, maximum root length (RL), the number of leaves(L), total leaf length (LL), total leaf width (LW), total leaf area (LA), the number of root tips (RT), the number of haustoria (H) and total dry weight (DW) in $M$. savatieri under different DMBQ concentrations and cultivation density treatments.

\begin{tabular}{|c|c|c|c|c|c|c|c|c|c|c|c|c|}
\hline Treatments & & $\mathrm{SH}$ & $\mathrm{RL}$ & $\mathrm{L}$ & LL & LW & LA & RT & $\mathrm{H}$ & DW & $\begin{array}{c}\text { Average } \\
\text { membership } \\
\text { function values }\end{array}$ & Rank \\
\hline $\begin{array}{l}\text { DMBQ } \\
\text { concentration }\end{array}$ & $\begin{array}{c}\text { Cultivation } \\
\text { density }\end{array}$ & & & & & & & & & & & \\
\hline 0 & 1 & 0.09 & 0.51 & 0.26 & 0.06 & 0.41 & 0.33 & 0.34 & 0.43 & 0.38 & 0.31 & 12 \\
\hline 0.1 & 1 & 0.83 & 0.81 & 0.71 & 0.36 & 0.69 & 0.54 & 0.54 & 0.61 & 0.59 & 0.63 & 3 \\
\hline 1 & 1 & 0.93 & 0.37 & 0.39 & 0.30 & 0.83 & 0.85 & 0.93 & 0.91 & 0.90 & 0.71 & 2 \\
\hline 10 & 1 & 0.81 & 0.88 & 0.94 & 0.76 & 0.71 & 0.74 & 0.71 & 0.82 & 0.61 & 0.78 & 1 \\
\hline 100 & 1 & 0.28 & 0.42 & 0.76 & 0.09 & 0.53 & 0.44 & 0.58 & 0.64 & 0.56 & 0.48 & 7 \\
\hline 1000 & 1 & 0.15 & 0.65 & 0.08 & 0.06 & 0.30 & 0.33 & 0.35 & 0.38 & 0.44 & 0.30 & 13 \\
\hline 0 & 2 & 0.52 & 0.45 & 0.36 & 0.33 & 0.38 & 0.38 & 0.56 & 0.30 & 0.50 & 0.42 & 9 \\
\hline 0.1 & 2 & 0.80 & 0.66 & 0.51 & 0.67 & 0.64 & 0.49 & 0.46 & 0.55 & 0.62 & 0.60 & 5 \\
\hline 1 & 2 & 0.72 & 0.54 & 0.29 & 0.52 & 0.66 & 0.54 & 0.59 & 0.50 & 0.57 & 0.55 & 6 \\
\hline 10 & 2 & 0.71 & 0.86 & 0.47 & 0.88 & 0.54 & 0.49 & 0.40 & 0.52 & 0.62 & 0.61 & 4 \\
\hline 100 & 2 & 0.46 & 0.57 & 0.26 & 0.55 & 0.51 & 0.38 & 0.19 & 0.43 & 0.30 & 0.41 & 10 \\
\hline 1000 & 2 & 0.33 & 0.49 & 0.13 & 0.30 & 0.23 & 0.28 & 0.28 & 0.25 & 0.25 & 0.28 & 14 \\
\hline 0 & 4 & 0.25 & 0.07 & 0.14 & 0.30 & 0.09 & 0.10 & 0.03 & 0.09 & 0.06 & 0.13 & 18 \\
\hline 0.1 & 4 & 0.40 & 0.46 & 0.07 & 0.61 & 0.25 & 0.26 & 0.18 & 0.17 & 0.44 & 0.31 & 11 \\
\hline 1 & 4 & 0.64 & 0.64 & 0.40 & 0.58 & 0.35 & 0.36 & 0.28 & 0.26 & 0.33 & 0.43 & 8 \\
\hline 10 & 4 & 0.48 & 0.29 & 0.33 & 0.42 & 0.19 & 0.31 & 0.12 & 0.20 & 0.19 & 0.28 & 15 \\
\hline 100 & 4 & 0.35 & 0.22 & 0.19 & 0.39 & 0.14 & 0.21 & 0.15 & 0.09 & 0.11 & 0.20 & 16 \\
\hline 1000 & 4 & 0.30 & 0.37 & 0.13 & 0.30 & 0.05 & 0.10 & 0.09 & 0.07 & 0.05 & 0.16 & 17 \\
\hline
\end{tabular}

the free uptake of water and nutrients. Under DMBQ induction, $M$. savatieri established relatively larger leaf and root systems (Figure 4). This probably contributed to an increase in its photosynthetic and absorptive area, which was positively correlated with increasing growth (Table 3). Furthermore, DMBQ-induced haustoria are covered by a small number of haustorial hairs (Figure $5 a$ ), and haustorial hairs dramatically increase the surface area of epidermal cells in P. japonicum (CUI et al., 2016). Hence, we suggested that the occurrence of haustorial hairs with haustorium formation mays lightly extend the root system of $M$. savatieri, thus promoting the uptake of water and nutrients. These results were consistent with the observation that the suppression of haustorium formation is associated with significant growth depression in Pedicularis tricolor (LI et al., 2012a). Although the promotion of haustorium formation may be beneficial to the root hemiparasite, further investigation is required to determine the causality between haustorium number and biomass in DMBQ-treated M. savatieri.

$M$. savatieri can initiate haustorium formation without the direct application of DMBQ solution, which suggested that the haustoriuminducing factors derived from the host are not absolutely necessary for haustorium formation in $M$. savatieri. This result is similar to findings in $T$. versicolor and pot-cultured P. tricolor, which produce haustoria without a host (YODER, 1997; LI et al., 2012a). However, Triphysaria eriantha does not form haustoria under sterile water treatment (JAMISON et al., 2001). The variations in haustorium formation may be explained by the differences between hemiparasitic species. Evolutionarily higher obligate parasites only initiate haustoria development in the presence of induction signals provided by the hosts (WESTWOOD et al., 2010), whereas the results observed here may have been caused by the lower degree of evolution of $M$. savatieri. In addition, the haustoria produced under DMBQ induction did not form xylem (Figure 5a). Similarly, DMBQ-treated P. japonicum forms xylem-free haustoria (CUI et al., 2016). These results from plants of the same family suggested that the establishment of mature haustoria may require a combination of various host-derived signals and physical contacts. In the absence of a host 

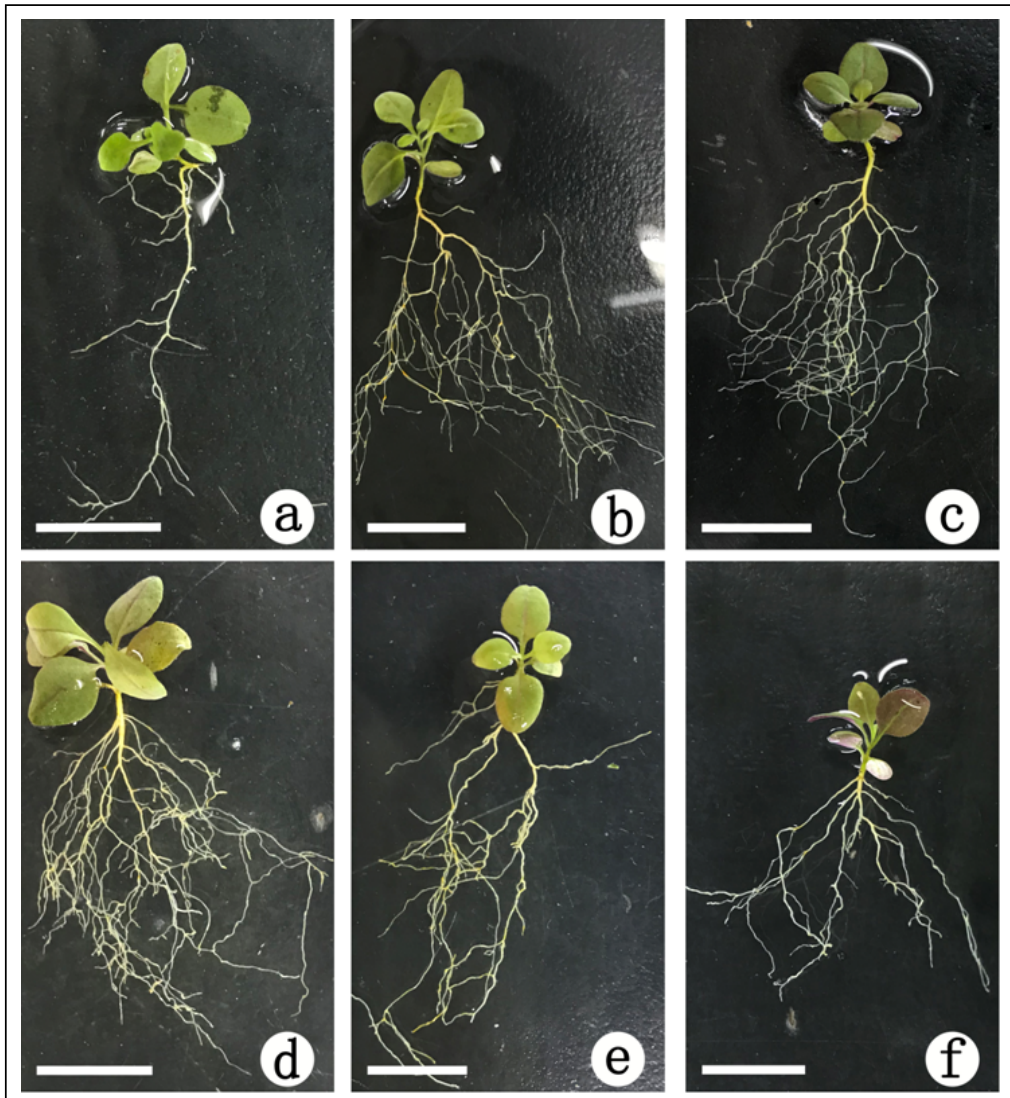

Figure 4 - Seedlings of $M$. savatieri grown under different DMBQ concentrations. (a) Control. (b) $0.1 \mu \mathrm{mol} \cdot \mathrm{L}^{-1} \mathrm{DMBQ}$. (c) $1 \mu \mathrm{mol} \cdot \mathrm{L}^{-1} \mathrm{DMBQ}$. (d) $10 \mu \mathrm{mol} \cdot \mathrm{L}^{-1}$ DMBQ. (e) $100 \mu \mathrm{mol} \cdot \mathrm{L}^{-1} \mathrm{DMBQ}$. (f) $1000 \mu \mathrm{mol} \cdot \mathrm{L}^{-1} \mathrm{DMBQ}$. Bars $=1 \mathrm{~cm}$.

plant, $M$. savatieri tends to allocate biomass slowly through the photosynthesis of leaves and nutrient uptake by the root system, allowing survival for at least 12 weeks. Without attaching to hosts, T. chinense can survive for up to 2 months (LUO et al., 2010). This explains why despite the differences in the duration of the pre-parasitic phase and host dependency prior to the initiation of functional haustoria, all root-hemiparasitic plants are able to survive for some period of time (ranging from a few hours to several months) without a host (SEEL et al.,1993).

During cultivation, we observed that $M$. savatieri formed haustoria between different plants of the same species or different lateral roots of the same plant, which can be considered selfparasitism (Figure 6). Within individual plants, the attachment of haustoria formed on lateral roots to either another lateral root (Figure 6c) or to another haustorium (Figure 6b) was also observed. In addition, $M$. savatieri formed haustorium-haustorium associations between two individuals (Figure 6d). In fact, self-parasitism of $M$. savatieri has been observed only in wild plants (ZHANG et al., 2015). Here, we reported self-parasitism during the hostfree artificial cultivation of $M$. savatieri and observed a xylem-bridge connection in the haustoria under self-parasitism for the first time (Figure 5b). Selfparasitism or auto-parasitism has been reported previously in facultative root hemiparasites, and the capacity for and conditions of auto-parasitization vary between species (PIEHL, 1963; ATSATT et al., 1978). In Cuscuta japonica cultured in vitro, far-red light can induce the occurrence of auto-parasitism (FURUHASHI et al., 1995). From an evolutionary perspective, a plant benefits little from parasitizing its own roots or those of other plants from the same species (WESTWOOD et al., 2010). Nevertheless, a small benefit is better than no gain, which may largely indicate an adaptive strategy of $M$. savatieri. In the wild, many seedlings of $M$. savatieri cannot 




successfully attach to a host within the necessary time period after seed germination. Therefore, we propose that the limited benefits obtained from the selfparasitism may be of great help to the survival of $M$. savatieri during the independent growth. Comparison of the number and structure of haustoria under self- parasitism and host interaction will provide more information in the near future.

The three tested cultivation densities showed different effects on the growth of $M$. savatieri under the same DMBQ concentration. When M. savatieri was grown at a high density (four plants per cell), the
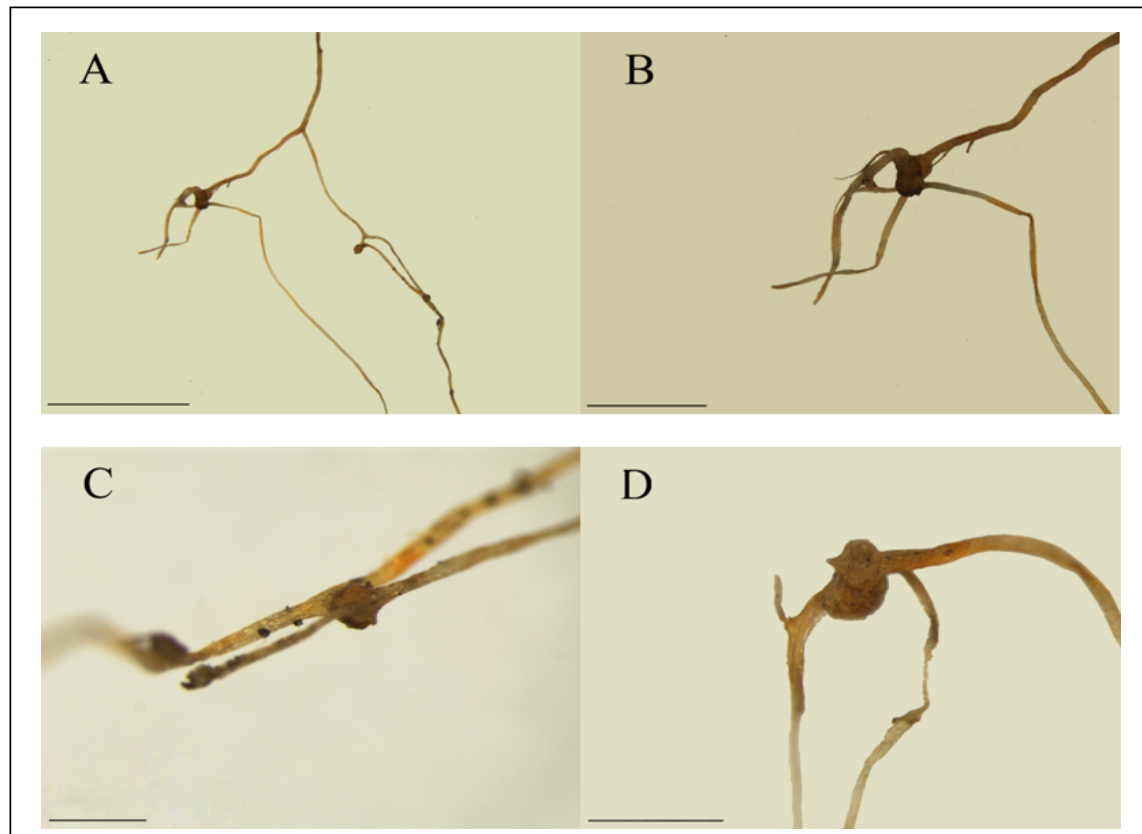

Figure 6 - Self-parasitism of M. savatieri. (a) Different lateral roots of the same individual under self-parasitism (Bar $=5 \mathrm{~mm}$ ). (b) Detailed view of self-parasitism in A showing the case where haustoria attach to haustoria $(B a r=2 \mathrm{~mm}$ ). (c) Detailed view of the selfparasitism in A showing the case where haustoria attach to lateral roots of the same individual $(\mathrm{Bar}=500 \mu \mathrm{m})$. (d) Haustoria of one plant attach to the haustoria of another plant $(\mathrm{Bar}=1 \mathrm{~mm})$. 
values of the membership function were lower than that at the other two cultivation densities (Table 4), which suggested that the overall growth of plants at a dense cultivation density was inferior to that at an intermediate or low cultivation density. A dense cultivation density readily leads to intraspecific competition under restricted soil and space conditions, which is mainly affected by the competition for water, light and soil nutrients. This result is supported by the population distribution of wild resources; $M$. savatieri grows well in sunny and moist terrains as colonies and is sparsely distributed in terrains with lower light and dry conditions (ZHANG et al., 2015). Regarding the competition for light, decreased survivorship in dense vegetation has been reported in the case of Rhinanthus minor (HULST et al., 1987). $M$ savatieri produces many active compounds (LI et al., 2012b; LIU et al., 2013; SHI et al., 2013), which may have an allelopathic effect on its growth at a high density. Further studies to reveal the effects of these compounds and the underlying mechanisms using single-factor experiments or orthogonal experiments are needed to aid in establishing a comprehensive cultivation system for $M$. savatieri.

\section{CONCLUSION}

As wild resources of $M$. savatieri are decreasing sharply, there is an urgent need to artificially acclimatize and cultivate this species to avoid extinction. By exploring the differential effects of DMBQ concentrations and cultivation densities on the growth of $M$. savatieri, an appropriate combination of the DMBQ concentration (10 $\mu \mathrm{mol} \cdot \mathrm{L}^{-1}$ ) and cultivation density (one plant per cell) was determined, which resulted in better overall performance in terms of growth traits, numbers of haustoria and biomass. Hence, the selection of the optimum DMBQ concentration and cultivation density may be an effective measure for the cultivation of $M$. savatieri. Apart from haustorium induction, the role of HIFs in the issue of attachment to a host could also be further discussed in the future artificial cultivation of $M$. savatieri.

\section{ACKNOWLEDGEMENTS}

The work was supported by a research fund (NO. HY0068) from the Huizhou Jiuhui Pharmaceutical Co., Ltd.

\section{DECLARATION OF CONFLICT OF INTERESTS}

The authors declare no conflict of interest. The founding sponsors had no role in the design of the study; in the collection, analyses, or interpretation of data; in the writing of the manuscript, and in the decision to publish the results.

\section{AUTHORS' CONTRIBUTIONS}

Lanlan Chen and Zaibiao Zhu contributed equally in the experiment and paper publication.

\section{REFERENCES}

ALBRECHT, H. et al. Flavonoids promote haustoria formation in the root parasite Triphysaria versicolor. Plant Physiology, v.119,p.585-591, 1999. Available from: <https://www.ncbi.nlm. nih.gov/pmc/articles/PMC32135/>. Accessed: Jul. 10, 2016.

ATSATT, P. R. et al. Chemical induction and repression of haustoria in Orthocarpus purpurascens (Scrophulariaceae). Annals of Botany, v.42,p.1177-1184, 1978.Available from:<https:// academic.oup.com/aob/article-abstract/42/5/1177/85194?redi rectedFrom $=$ fulltxt $>$. Accessed: Sep. 10, 2016. doi: 10.1093/ oxfordjournals.aob.a085559.

BANDARANAYAKE, P. C. G. et al. A single-electron reducing quinone oxidoreductase is necessary to induce haustorium development in the root parasitic plant Triphysaria. Plant Cell, v.22, p.1404-1419, 2010. Available from: <https:/www.ncbi.nlm. nih.gov/pmc/articles/PMC2879752/>. Accessed: Sep. 23, 2017, doi: $10.1105 /$ tpc. 110.074831 .

CALLADINE, A. et al. Haustorial development and growth benefit to seedlings of the root hemiparasitic tree Nuytsia floribunda (Labill.) R.Br. in association with various hosts. Annals of Botany, v.85, p.733-740, 2000. Available from: $<$ https://academic. oup.com/aob/article/85/6/733/2588201>. Accessed: Oct. 27, 2017. doi: $10.1006 /$ anbo. 2000.1129 .

CHANG, M. et al. The haustorium and the chemistry of hos recognition in parasitic angiosperms. Journal of Chemical Ecology, v.12, p.561-579, 1986. Available from: <https://link. springer.com/article/10.1007/BF01020572>. Accessed: Oct. 20, 2016. doi: 10.1007/BF01020572.

CHEN, Y. F. et al. Effects of Gibberellin concentration and temperature on seeds germination of Monochasma savatieri. Journal of Chinese Medicinal Materials, v.41, p.10401043, 2018. Available from: <http://www.cnki.com.cn/Article/ CJFDTotal-ZYCA201805007.htm>. Accessed: Feb. 20, 2019. doi: 10.13863/j.isn1001-4454.2018.05.006.

CHUANG, T. I. et al. Observations on root-parasitism in Cordylanthus (Scrophulariaceae). American Journal of Botany, v.58, p.218-228, 1971. Available from: <https://bsapubs. onlinelibrary.wiley.com/doi/abs/10.1002/j.1537-2197.1971. tb09966.x>. Accessed: Sep. 15, 2018. doi: 10.1002/j.15372197.1971.tb09966.x.

CUI, S. K. et al. Haustorial hairs are specialized root hairs that support parasitism in the facultative parasitic plantphtheirospermum japonicum. Plant Physiology, v.170, p.1492-1503, 2016. Available from: <http://www.plantphysiol.org/content/170/3/1492>. Accessed: Apr. 29, 2018. doi: 10.1104/pp.15.01786.

Environment Agency of Japan. Threatened wildlife of Japan, Red data book. In: Environment Agency of Japan. Vascular plants. Tokyo: Japan Wildlife Research Center, 2000. Cap.8, p.660.

Ciência Rural, v.50, n.3, 2020. 
FURUHASHI, K. et al. Photocontrol of parasitism in a parasitic flowering plant, Cuscuta japonica Chois, cultured in vitro. Plant and Cell Physiology, v.36, p.533-536, 1995. Available from: $<$ https://academic.oup.com/pcp/article-abstract/36/3/533/1912052 ?redirectedFrom=fulltext $>$. Accessed: Nov. 05, 2017. doi: 10.1093/ oxfordjournals.pcp.a078790.

GUO, Q. S. et al. Comparative studies on the growth, chlorophyll, amino acids and minerals of Thesium chinense (Santalaceae) in association with different hosts. Nordic Journal of Botany, v.28, p.632-640, 2010. Available from: $<$ https://onlinelibrary.wiley.com/ doi/full/10.1111/j.1756-1051.2010.00791.x>. Accessed: Jan. 12, 2017. doi: 10.1111/j.1756-1051.2010.00791.x.

HEIDE-JØRGENSEN, H. S. Introduction: the parasitic syndrome in higher plants. In: Joel, D.M.; Gressel, J.; Musselman, J. Parasitic Orobanchaceae.Heidelberg: Springer, 2013. p.1-18.

HONG, D. et al. Scrophulariaceae. In: Wu, Z.Y.; Raven, P.H. Flora of China. Beijing: Science Press and Missouri Botanical Garden Press, 1998. p.211-212.

HULST, V. R. et al. Why is Rhinanthus minor (Scrophulariaceae) such a good invader? Canadian Journal of Botany, v.65, p.23732379, 1987. Available from: <https://www.nrcresearchpress.com/ doi/10.1139/b87-322\#.XRyVga274zY>. Accessed: May, 12, 2019. doi: $10.1139 / \mathrm{b} 87-322$.

ISHIDA, J. K. et al. Local auxin biosynthesis mediated by a YUCCA flavin monooxygenase regulates haustorium development in the parasitic plant Phtheirospermum japonicum. Plant Cell, v.28, p.1795-1814, 2016. Available from: <http://www.plantcell. org/content/28/8/1795>. Accessed: Feb. 10, 2018. doi: 10.1105/ tpc. 16.00310 .

JAMISON, D. S. et al. Heritable variation in quinone-induced haustorium development in the parasitic plant Triphysaria. Plant Physiology, v.125,p.1870-1879, 2001. Available from: <https:// www.ncbi.nlm.nih.gov/pmc/articles/PMC88842/>. Accessed: Oct. 09, 2017. doi: 10.1104/pp.125.4.1870.

KEYES, W. J. et al. Signaling organogenesis in parasitic angiosperms: xenognosin generation, perception, and response. Journal of Plant Growth Regulation, v.19, p.217231, 2000. Available from: <https:/www.ncbi.nlm.nih.gov/ pubmed/11038229>. Accessed: Apr. 28, 2019. doi: 10.1007/ s003440000024.

KIM, D. et al. On becoming a parasite: evaluating the role of wall oxidases in parasitic plant development. Chemistry \& Biology, v.5, p.103-117, 1998. Available from: <https://www.ncbi.nlm.nih. gov/pubmed/9495831>. Accessed: Apr. 29, 2019. doi: 10.1016/ S1074-5521(98)90144-2.

LI, A. R. et al. Inoculation with arbuscular mycorrhizal fungi suppresses initiation of haustoria in the root hemiparasite Pedicularis tricolor. Annals of Botany, v.109, p.1075-1080, 2012a. Available from: <https://www.ncbi.nlm.nih.gov/pmc/articles/PMC3336945/>. Accessed: Jul. 17, 2018. doi: 10.1093/aob/mcs028.

LI, M. et al. Phenylethanoid glycosides from Monochasma savatieri and their anticomplement activity through the classical pathway. Planta Medica, v.78,p.1381-1386, 2012b. Available from: $\quad<$ https://www.thieme-connect.de/products/ejournals/abs tract/10.1055/s-0033-1350879>. Accessed: Oct. 20, 2016. doi: $10.1055 / \mathrm{s}-0033-1350879$.
LIU, Y. L. et al. Antimicrobial, anti-inflammatory activities and toxicology of phenylethanoid glycosides from Monochasma savatieri Franch. ex Maxim. Journal of Ethnopharmacology, v.149, p.431-437, 2013. Available from: <https://www.sciencedirect.com/science/article/pii/ S0378874113004625?via\%3Dihub>. Accessed: Sep. 19, 2016. doi:10.1016/j.jep.2013.06.042.

LUO, F. L. et al. Influences ofhost species on transpiration, photosynthesis, chlorophyll and mineral contents of medicinal hemiparasite Thesium chinense Turcz. Acta Physiologiae Plantarum, v.32, p.1093-1102, 2010. Available from: <https:// link.springer.com/article/10.1007\%2Fs 11738-010-0501-2>. Accessed: Apr. 27, 2017. doi: 10.1007/s11738-010-0501-2.

MUSSELMAN, L. J. Observations on the life history of Aureolaria grandiflora and Aureolaria pedicularia (Scrophulariaceae). TheAmerican Midland Naturalist, v.82, p.307-311, 1969. Available from: <https://www.jstor.org/stable/2423848?origin=cr ossref\&seq=1\#metadata_info_tab_contents $>$. Accessed: Nov. 01, 2016. doi: $10.2307 / 2423848$.

NGO, Q. A. et al. The differentially regulated genes $T v Q R 1$ and TvPirin of the parasitic plant Triphysaria exhibit distinctive natural allelic diversity. BMC Plant Biology, v.13, p.28-38, 2013. Available from: $<$ https://bmcplantbiol.biomedcentral.com/ articles/10.1186/1471-2229-13-28>. Accessed: Mar. 08, 2018. doi: 10.1186/1471-2229-13-28.

PIEHL, M. A. Mode of attachment, haustorium structure, and hosts of Pedicularis canadensis. American Journal of Botany, v.50, p.978-985, 1963. Available from: <https://www.jstor.org/ stable/2439904?seq=1\#metadata_info_tab_contents $>$. Accessed: May, 5, 2017.

SEEL, W. E. et al. Do inorganic solutes limit growth of the facultative hemiparasite Rhinanthus minor L. in the absence of a host. New Phytologist, v.124, p.283-289, 1993. Available from: <https:// nph.onlinelibrary.wiley.com/doi/abs/10.1111/j.1469-8137.1993. tb03818.x>. Accessed: Sep. 09, 2016. doi: 10.1111/j.14698137.1993.tb03818.x.

SHENG, Y. L. et al. Comprehensive evaluation on drought resistance of flue-cured tobacco varieties at seedling stage by subordinate function values analysis. Journal of Southern Agriculture, v.45, p.1751-1758, 2014. Available from: <http:// www.cnki.net>. Accessed: Jun. 06, 2018. doi: 10.3969/j:is sn.2095-1191.2014.10.1751.

SHI, M. F. et al. Protective effect of total phenylethanoid glycosides from Monochasma savatieri Franch on myocardial ischemia injury. Phytomedicine, v.20, p.1251-1255, 2013. Available from: <https://www.sciencedirect.com/science/article/ pii/S0944711313002419? via\%3Dihub>. Accessed: Oct. 29, 2016. doi: 10.1016/j.phymed.2013.06.014.

TOMILOV, A. A. et al. Localized hormone fluxes and early haustorium development in the hemiparasitic plant Triphysaria versicolor. Plant Physiology, v.138, p.1469-1480, 2005. Available from: <http://www.plantphysiol.org/content/138/3/1469>. Accessed: Jun. 09, 2017. doi: 10.1104/pp.104.057836.

WESTWOOD, J. H. et al. The evolution of parasitism in plants. Trends in Plant Science, v.15, p.227-235, 2010. Available from: <https://www. sciencedirect.com/science/article/pii/S1360138510000075?via\%3Dihub>. Accessed: Feb. 02, 2018. doi: 10.1016/j.tplants.2010.01.004. 
YAMAZAKI, T. Scorphulariaceae. In: Iwatsuki, K.; Yamazaki, T.; Bufford, D.E.; Ohba, H. Flora of Japan. Tokyo: Smithsonian Institution Press, 1993. p.358-359.

YANG, Y. Z. Plantlet regeneration of Monochasma savatieri Franch. ex Maxim. in vitro culture from inducing adventitious root. Plant Physiology Communications, v.7, p.693-694, 2009. Available from: <http://www.cnki.com.cn/Article/CJFDTotalZWSL200907020.htm>. Accessed: Nov. 11, 2016. doi: 10.13592/j. cnki.ppj.2009.07.011.

YODER, J. I. A species-specific recognition system directs haustorium development in the parasitic plant Triphysaria (Scrophulariaceae). Planta, v.202, p.407-413, 1997. Available from: <https://link.springer.com/article/10.1007\% 2Fs004250050144>. Accessed: Nov. 01, 2017. doi: 10.1007/ s004250050144.

YOSHIDA, S. et al. Plants that attack plants: molecular elucidation of plant parasitism. Current Opinion in Plant Biology, v.15,p.708-713, 2012. Available from: <https://www.sciencedirect.com/science/
article/pii/S136952661200101X?via\%3Dihub>. Accessed: Mar. 13, 2018. doi: 10.1016/j.pbi.2012.07.004.

YOSHIDA, S. et al. The haustorium, a specialized invasive organ in parasitic plants. Annual Review of Plant Biology, v.67, p.643667, 2016. Available from: <https://www.annualreviews.org/doi/ full/10.1146/annurev-arplant-043015-111702>. Accessed: Mar. 23, 2019. doi: 10.1146/annurev-arplant-043015-111702.

ZHANG, M. H. et al. The biology and haustorial anatomy of semiparasitic Monochasma savatieri Franch. ex Maxim. Plant Growth Regulation, v.75, p.473-481, 2015. Available from: <https:// link.springer.com/article/10.1007\%2Fs 10725-014-0010-1>. Accessed: Aug. 18, 2016. doi: 10.1007/s10725-014-0010-1.

ZHANG, Y. Y. et al. Adventitious shoot induction from internode and root explants in a semiparasitic herb Monochasma savatieri Franch ex Maxim. Journal of Plant Growth Regulation, v.36, p.799-804, 2017. Available from: <https://link.springer.com/ article/10.100.7\%2Fs00344-017-9681-y>. Accessed: Aug. 18, 2018. doi: 10.1007/s00344-017-9681-y. 